\title{
Islam and matriliny along the Indian Ocean rim: Revisiting the old 'paradox' by comparing the Minangkabau, Kerala and coastal northern Mozambique
}

\author{
Liazzat J.K. Bonate
}

\begin{abstract}
The coexistence of Islam and matriliny has been viewed as a 'paradox' because of strict patriliny that Islam prescribes. This article attempts to disentangle this enigma by comparing the Minangkabau, Kerala and coastal northern Mozambique that represent the most well-known cases of simultaneous practice of Islam and matrilineal kinship, which initially was a result of peaceful Islamisation through Indian Ocean networks. In the nineteenth century, the Dutch and British colonial regimes helped matriliny to survive, despite all the efforts of the Islamists to the contrary, by codifying local juridical rules. The Portuguese integration of the local matrilineal nobility into their colonial administrative system preserved matriliny within the local Muslim order. Nowadays these communities are influenced by modernisation, nation-state policies, and Islamic reformist movements, but matrilineal principles still regulate the use of the ancestral land.
\end{abstract}

The most well-known examples of the coexistence of matriliny and Islam in a longue durée are the Minangkabau in West Sumatra in Indonesia and Negeri Sembilan in Malaysia, Muslim communities in Kerala and in the Lakshadweep Islands in India and, to a lesser extent, in coastal northern Mozambique in southeastern Africa. ${ }^{1}$ While each of these examples represents a particular case, collectively they epitomise a 'paradox', given that the normative Islam mandates patrilineal

Liazzat Bonate is a Lecturer at the Department of History, The University of the West Indies, Saint Augustine, Trinidad and Tobago. Correspondence in connection with this paper should be addressed to: Liazzat.Bonate@sta.uwi.edu. The author would like to thank Seoul National University for the University Research Grant that supported this study in 2011-12.

1 The Yao and Muslim Makua of the mainland in Mozambique, Tanzania and Malawi also fall into this category, but are not covered by this article. And of course, there are other regions along the so-called 'matrilineal belt of Africa' where matriliny and Islam have coexisted, such as among the Mandinka of Senegal, Akan in Ghana, and others. See for example, Jean Davison, Gender, lineage and ethnicity in Southern Africa (Boulder, CO: Westview, 1997); Edward A. Alpers, 'Towards a history of the expansion of Islam in East Africa: The matrilineal peoples of the southern interior', in The historical study of African religion, ed. Terence O. Ranger and I.N. Kimambo (London: Heinemann, 1972), pp. 172-201; Christine Okali, Cocoa and kinship: The matrilineal Akan of Ghana (London: Routledge, 1983). 
kinship, inheritance, succession and residence patterns as well as the patriarchal family. By comparing these regions, this article argues that they have much more in common in terms of historical and cultural characteristics, which might shed light on how this 'paradox' came into being and why it still persists.

Based on an analysis of mostly secondary literature except for northern Mozambique, where fieldwork and archival research were conducted, this article first outlines the expansion of Islam into these regions along the Indian Ocean trading networks. Second, it looks comparatively into how the rise of Islamic reformers and colonial regimes influenced matriliny and Islam. Lastly, this study compares and contrasts the ways in which matriliny has been conceived and practised in these regions in contemporary, post-colonial settings.

\section{The Indian Ocean and Islamisation}

Although separated by considerable distances, all these regions are situated along the Indian Ocean rim and were involved in long-term historical relations linking the Indian Ocean world with their respective mainland.

The acceptance of Islam by local populations took place between the eighth and fifteenth centuries when trade in the Indian Ocean was dominated by Muslims to the extent that it came to be regarded as a 'Muslim lake'. ${ }^{2}$ Muslim trade networks and Islam represented one of the factors for the unity of the Indian Ocean, but the spread of Islam was not even or consistent; nor were Muslims the only traders in this Ocean. ${ }^{3}$ Islam came to the northern Mozambican and Malabar coasts very early, perhaps in the eighth century, through routes that were already in place long before the Muslim faith emerged. ${ }^{4}$ These routes linked the Red Sea coast, the Persian Gulf, South India, South Arabia, Persia, Southeast Asia, East Africa and China to each other and to the wider Indian Ocean web of connections and exchange. ${ }^{5}$

Matrilineal Austronesian seafarers and traders from Western Indonesia and the Malay Peninsula traversed the Indian (and the Pacific) Ocean and linked India, China, Sri Lanka and East Africa to Southeast Asia, triggering major migrations of food culture, animals, musical instruments and maritime technology. ${ }^{6}$ The migrants

2 Michael Pearson, The Indian Ocean (London: Routledge, 2003), p. 95.

3 Michael Lambek, 'Localising Islamic performances in Mayotte', in Islamic prayer across the Indian Ocean: Inside and outside the mosque, ed. David Parkin and Stephen Headley (Richmond: Curzon, 2000), p. 64.

4 K.N. Chaudhuri, Trade and civilization in the Indian Ocean: An economic history from the rise of Islam to 1750 (Cambridge: Cambridge University Press, 1985), pp. 37-9; Roland E. Miller, Mappila Muslims of Kerala: A study in Islamic trends (Madras: Orient Longman, 1992), pp. 39-46, 51; M.H. Ilias, 'Mappila Muslims and the cultural content of trading Arab diaspora on the Malabar Coast', Asian Journal of Social Sciences 35, 4/5 (2007): 436, 439; Ricardo Teixeira Duarte, Northern Mozambique in the Swahili world (Stockholm: Central Board of National Antiquities; Maputo: Dept. of Archaeology and Anthropology, Eduardo Mondlane University; Uppsala: Dept. of Archaeology, 1993); Malyn Newitt, 'The early history of the Sultanate of Angoche', Journal of African History 13, 3 (1972): 397-406; Malyn Newitt, A history of Mozambique (London: Hurst \& Co., 1995), pp. 3-13; Liazzat J. K. Bonate, 'Islam in northern Mozambique: A historical overview', History Compass 8, 7 (2010): 574.

5 The Periplus of the Erythraean Sea: Travel and trade in the Indian Ocean by a merchant of the first century, http://www.fordham.edu/halsall/ancient/periplus.asp (last accessed 25 Sept. 2014).

6 Craig A. Lockard, Southeast Asia in world history (Oxford: Oxford University Press, 2009), p. 15. 
settled along the East African coast, including Mozambique, by the first century BCE and sometime between 100 and $700 \mathrm{CE}$ formed permanent communities on Madagascar. ${ }^{7}$ A large number of Indonesian seamen, who were not Muslims yet, had reached and raided the Mozambican coastline in the tenth century. ${ }^{8}$

The Malayo-Austronesians were instrumental in spreading Buddhism and later, Hinduism from India into Southeast Asia from the seventh century BCE to the first century CE. ${ }^{9}$ In the fourth century CE there was a widespread adoption of Buddhist and Hindu beliefs, Sanskrit terms and script, and of coinage, all reflecting the influences from the Indian subcontinent. However, much of this cultural adoption was done by dynastic leaders of Srivijaya and Majapahit in Sumatra and Java as 'means by which local leaders may claim special knowledge and thereby reaffirm their claim for authority.'. ${ }^{10}$

When the ports in southern India, Arabia and Persia became Islamised, the Malay and Indonesian seafarers and traders were influenced by the new religion, and through their interaction with Muslim merchants and together with the newly converted Southeast Asian and southern Chinese Muslims, they Islamised the entire region. ${ }^{11}$ The involvement of the northern Sumatran kingdom of Samudra-Pasai within the Indian Ocean networks in the thirteenth century resulted in it becoming the first political entity to accept Islam as a court religion in the region. ${ }^{12}$ By the 1500s, there were several Muslim states in Sumatra, Java, Sulawesi, and the Moluccas, while other regions adopted Islam later.

Archaeological evidence suggests that Muslim sailors and merchants probably stayed through monsoon periods or used as respites the islands or the littoral of northern Mozambique on their way to the coastal ports that linked the Indian Ocean to the southern African gold-mining mainland regions probably from the eighth century onwards. ${ }^{13}$ As a stopover for merchants sailing from the Red Sea to Southeast Asia,

7 Kenneth R. Hall, A history of early Southeast Asia: Maritime trade and societal development, 100-1500 (Lanham, MD: Rowman and Littlefield, 2011), p. 5.

8 Marilee Wood, Laure Dussubieux and Peter Robertshaw, 'The glass of Chibuene, Mozambique: New insights into early Indian Ocean trade', South African Archaeological Bulletin 67, 195 (2012): 72-3; Pearson, The Indian Ocean, pp. 60-61.

9 Monica L. Smith, "Indianization" from the Indian point of view: Trade and cultural contacts with Southeast Asia in the early first millennium C.E.', Journal of the Economic and Social History of the Orient (JESHO) 42, 1 (1999): 6-8; Kenneth R. Hall, 'Small Asian nations in the shadow of the large: Early Asian history through the eyes of Southeast Asia', JESHO 27, 1 (1984): 68-9; M.C. Ricklefs, Bruce Lockhart, Portia Reyes and Maitrii Aung-Thwin, A new history of Southeast Asia (Basingstoke: Palgrave Macmillan, 2010), pp. 19-22.

10 Smith, "Indianization" from the Indian point of view', pp. 11-12.

11 Kenneth R. Hall, 'Local and international trade and traders in the Straits of Melaka region: 6001500', JESHO 47, 2 (2004): 231-2, 234, 247, 251; Kenneth R. Hall, 'Multi-dimensional networking: Fifteenth-century Indian Ocean maritime diaspora in Southeast Asian perspective', JESHO 49, 4 (2006): 454-81.

12 Elizabeth Lambourn, 'Tombstones, texts, and typologies: Seeing sources for the early history of Islam in Southeast Asia', JESHO 51, 2 (2008): 252-86; Kenneth R. Hall, 'Upstream and downstream in Southeast Asia's first Islamic polity: The changing sense of community in the fifteenth century Hikayat Raja-Raja Pasai court chronicle', JESHO 44, 2 (2001): 198-229; Vincent J.H. Houben, 'Southeast Asia and Islam', Annals of the American Academy of Political and Social Sciences 588 (July 2003): 153; Wazir Jahan Karim, Women and culture: Between adat and Islam (Boulder, CO: Westview, 1992), pp. 58-60.

13 Duarte, Northern Mozambique in the Swahili world. 
the Malabar Coast also attracted itinerant merchant communities. ${ }^{14}$ These traders might have led some local people towards Islamisation during these short stays. But in later periods, more often than not, foreign merchants and sailors took local wives and many also settled permanently and were absorbed by local communities. The offspring of these migrant Muslims are credited with the formation of new ethnic groups, such as the Koti, Naharra, Mwani and other Swahili peoples of northern Mozambique, and the Mappila of Malabar. In the fourteenth century, Ibn Battuta witnessed the presence of local Muslim communities along with merchants from various parts of the Arab world, India and Persia along the Malabar and East African coasts. ${ }^{15}$ Home-grown converts expanded Islam further along the coast and into the mainland. When the Portuguese arrived at the end of the fifteenth and early sixteenth centuries, they found that in both regions foreign mercantile as well indigenous Muslim communities were thriving. ${ }^{16}$

Although the settlement of the Lakshadweep Islands off the coast of Malabar took place in about the second century BCE, A.R. Kutty and Leela Dube suggest that Islamisation there occurred only in the fourteenth century CE under the influence of the immigrants from Malabar, while Andrew Forbes argues that it might have happened much earlier due to the impact of the South Arabian Hadrami sailors and merchants. ${ }^{17}$

The conversion of the Minangkabau of West Sumatra probably occurred later than that of people in other parts of Southeast Asia in the fifteenth and sixteenth centuries when their region was drawn into the international trading networks. ${ }^{18} \mathrm{As}$ Tsuyoshi Kato underscores, it is not clear when exactly the Minangkabau accepted Islam, but an early-sixteenth-century account reports at least one Minangkabau king as Muslim. ${ }^{19}$ The Aceh sultanate controlled the region at the time and probably spread Islam there. Around the same period in the 1500s, the Minangkabau settlements in Negeri Sembilan on the Malay Peninsula developed. Michael Peletz maintains that 'Minangkabau males engaged in voluntary migration (merantau) navigated the narrow Straits of Malacca, sailed up the Linggi and Rembau rivers, and founded settlements in Negeri Sembilan and Malacca, just to the south. ${ }^{20}$

14 Ilias, 'Mappila Muslims': 443.

15 Pearson, The Indian Ocean, pp. 75-6; Stephen Frederic Dale, Islamic society on the South Asian frontier: The Mappilas of Malabar, 1498-1922 (Oxford: Clarendon, 1980), pp. 24-8.

16 Miller, Mappila Muslims of Kerala, pp. 32-45, 65; Newitt, A history of Mozambique, pp. 13-23; Edward A. Alpers, 'East Central Africa', in The history of Islam in Africa, ed. Nehemia Levtzion and Randall L. Pouwels (Athens: Ohio University Press; Oxford: James Currey; Cape Town: David Philip, 2000), p. 304; Dale, Islamic society on the South Asian frontier, pp. 34-42.

17 A.R. Kutty, Marriage and kinship in an island society (Delhi: National Publishing House, 1972), p. 9; Leela Dube, Matriliny and Islam: Religion and society in the Laccadives (Delhi: National Publishing House, 1969), p. 12; A.D.W. Forbes, 'Southern Arabia and Islamisation of the central Indian Ocean archipelagos', Archipel 21 (1981): 66, 81.

18 Karim, Women and culture, pp. 61-2.

19 Tsuyoshi Kato, Matriliny and migration: Evolving Minangkabau traditions in Indonesia (Ithaca: Cornell University Press, 1982), pp. 67-8; Jeffrey Hadler, Muslims and matriarchs: Cultural resilience in Indonesia through jihad and colonialism (Ithaca: Cornell University Press, 2008), p. 19.

20 Michael Gates Peletz, A share of the harvest: Kinship, property, and social history among the Malays of Rembau (Berkeley: University of California Press, 1988), pp. 15-16; see also, Kato, Matriliny and migration, pp. 86-8. 
There they converted to Islam under the influence of the international Islamic trading community and the emerging Muslim kingdoms.

In all regions under consideration, the Indian Ocean networks produced Sunni Muslims following the Shafi'i legal school (Ar., maddhab), a fact already noted by Ibn Battuta for fourteenth-century East Africa and Malabar. In all cases, the waves of migrations from the Hadramawt region of southern Yemen had consolidated particular high-status groups claiming to be descendants of the Prophet Muhammad, the Awlad Sharif. The sharifs in northern Mozambique and in Kerala enjoyed kinship relations with local ruling or upper class clans and their high social status resulted from both alliances with the elites and from their own sharifian descent. Hadrami sharifs are indicated as ancestors of many northern Mozambican coastal rulers. ${ }^{21}$ As early as in 1517, a letter from the leader of Mozambique (probably Mozambique Island and adjacent area) to the Portuguese King Manuel was signed by Sharif Muhammad al-Alawi, a name which points to his possible Hadrami Alawi sharifian pedigree. ${ }^{22}$ Besides the honorific titles of sharif and sayyid (Ar., lord), this group possessed additional special designations such as koya and thangal in the Lakshadweep Islands and in Malabar. The term koya denotes the land-owning Muslims who converted to Islam from higher Hindu castes of Brahmins and Nayars, but who claimed a sharifian descent simultaneously. ${ }^{23}$ According to A.R. Kutty and Leela Dube, 'koya is a corrupt equivalent of the Arabic word khoja, meaning "the respected"'. ${ }^{24}$ Their position as formerly high-caste Hindus with land-owning birthrights was strengthened by their engagement in trans-oceanic trade through the centuries and by their monopoly over the ownership of sailing craft. ${ }^{25}$ They were further empowered by their sharifian ancestry which granted them exclusive rights over vital Muslim communal activities, and they usually served as kazi (qadi, the Muslim judge), imams of the Juma mosque (central mosque) and heads of the Sufi Orders (the khalifa). ${ }^{26}$

Although individual Hadrami sharifs might have migrated earlier, their widespread settling in Southeast Asia occurred later than in the Malabar and East African coasts. In the first half of the eighteenth century, significant numbers of the Hadrami sayyids resided in Aceh, Borneo and south Sumatra. ${ }^{27}$ Engseng Ho

21 Liazzat J.K. Bonate, 'Traditions and transitions: Islam and chiefship in northern Mozambique, ca. 1850-1974' (PhD diss., University of Cape Town, 2007).

22 João de Sousa, Documentos arabicos para a historia portugueza copiados dos originaes da Torre do Tombo com permissão da S. Majestade, e vertidos em portuguez, por ordem da Academia Real das Sciencias de Lisboa (Lisboa: Officina da Academia Real das Sciencia, 1789), pp. 85-6.

23 Miller, Mappila Muslims of Kerala, pp. 42, 255-6; Dale, Islamic society, pp. 127-37; Ilias, 'Mappila Muslims': 448; Forbes, 'Southern Arabia and Islamization': 87; Aleena Sebastian, 'Matrilineal practices among Koyas of Kozhikode', Journal of South Asian Studies 1, 1 (2013): 69.

24 Kutty, Marriage and kinship, p. 20; Dube, Matriliny and Islam, p. 15.

25 Sebastian, 'Matrilineal practices': 66; Kutty, Marriage and kinship, p. 21; Dube, Matriliny and Islam, p. 17.

26 Kutty, Marriage and kinship, p. 22; Ilias, 'Mappila Muslims': 449; Dube, Matriliny and Islam, p. 18; Forbes, 'Southern Arabia and Islamization': 87; Filippo Osella and Caroline Osella, 'Islam and social reform in Kerala, South India', Modern Asian Studies 42, 2/3 (2008): 326.

27 Natalie Mobini-Kesheh, The Hadrami awakening: Community and identity in the Netherlands East Indies, 1900-1942 (Ithaca: SEAP, Cornell University, 1999), pp. 21-8; Ismail Fajrie Alatas, 'Becoming Indonesians: The Ba 'Alawi in the interstices of the nation', Die Welt des Islams 51, 1 (2011): 48. 
mentions that they settled among the Minangkabau in the same century, and one of them married the daughter of a local Rajah. ${ }^{28}$ Here too, the intermarriage between the Arab sharifs and local kings and other aristocracy, underlined the importance of 'the precious gift' of Prophetic genealogy for producing new Islamic elites. ${ }^{29}$

The arrival of the Hadrami sharifs went hand-in-hand with the launching of the Sufi Orders both in Lakshadweep and among the mainland Mappila communities, where the Rifa'i, Qadiri, and Alawi (and later, Chisti) tai'fas (Ar., branches) were founded and headed by the thangal and Koyas, who led the weekly $d h i k r$ ceremonies, annual celebration of the Prophet Muhammad's and local Sufi saints' birthday celebrations (maulood or mawlid) and the nerchara tomb visitations. ${ }^{30}$ In northern Mozambique and among the Minangkabau, the Sufi Orders emerged much later, but were also dominated by the Hadrami sharifs entwined with local political and land-owning elites. ${ }^{31}$

In all regions under consideration, Islamisation did not annihilate the preexisting matriliny, and matrilineal kinship continued to be at the base of social relations so that families and lineages and associated with them, inheritance, succession and residence patterns were constituted through mothers, and their daughters and sons. $^{32}$ Children were raised by mothers and maternal relatives. As Evelyn Blackwood points out, among the Minangkabau, matriliny empowered women 'as controllers of land and houses, creating an obvious dissonance with the masculinist discourses of the state, Islam and capitalism' ${ }^{33}$ And as such it stood in stark contrast with the prescribed norms of Islam, which not only define kinship patrilineally and put men at the apex of power relations within families as well as wider society, but also provide detailed legal injunctions on inheritance and the rearing of children. ${ }^{34}$ Scholars have long puzzled over the reasons for the 'paradox' of Islam not eradicating conflicting local matriarchal and matrilineal practices in these regions.

Michael Lambek suggests one of the most compelling reasons for the concurrent existence of Islamic and pre-Islamic practices among Muslims of the East African island of Mayotte. He argues that in the context of Indian Ocean-wide Islamisation, it is more accurate to speak of 'acceptance of rather than 'conversion to' Islam. ${ }^{35}$

28 Engseng Ho, The graves of Tarim: Genealogy and mobility across the Indian Ocean (Berkeley: University of California Press, 2006), pp. 162-3.

29 Ho, The graves of Tarim, pp. 171-3.

30 Osella and Osella, 'Islam and social reform in Kerala'; Forbes, 'Southern Arabia and Islamisation'; Miller, Mappila Muslims of Kerala, pp. 242, 257-60; Dale, Islamic society, pp. 112-18; Kutty, Marriage and kinship, pp. 26, 80-82; Dube, Matriliny and Islam, p. 26.

31 Bonate, 'Traditions and transitions'; Michael Laffan, The makings of Indonesian Islam: Orientalism and the narration of a Sufi past (Princeton, N.J.: Princeton University Press, 2011).

32 Peletz, A share of the harvest, p. 18; Evelyn Blackwood, 'Representing women: The politics of Minangkabau adat writing', Journal of Asian Studies 60, 1 (2001): 130; Sebastian, 'Matrilineal practices'; Kutty, Marriage and kinship; Dube, Matriliny and Islam; Liazzat J.K. Bonate, 'Matriliny, Islam and gender in northern Mozambique', Journal of Religion in Africa 36, 2 (2006): 139-66.

33 Evelyn Blackwood, Webs of power: Women, kin, and community in a Sumatran village (Lanham, MD: Rowman and Littlefield, 2000), p. 1.

34 Jamal J. Nasir, The Islamic law of personal status, 2nd ed. (London: Graham and Trotman, 1990); Dawoud El Alami and Doreen Hinchliffe, Islamic marriage and divorce laws of the Arab world (London: Kluwer Law International for CIMEL SOAS, 1996).

35 Lambek, 'Localising Islamic performances', p. 65. 
Conversion 'privileges an immediate, virtually instantaneous, unidirectional, and distinct shift in self-identification over a gradual change ... insofar as it privileges a private, subjective experience over a collective process; and insofar as it privileges rationalised "beliefs" over ritual order ...' ${ }^{36}$ Acceptance, on the other hand, as David Parkin points out, does not imply an abrupt abandonment of prevailing ideas and practices; it is a process 'which is likely to take longer and to be reciprocally inscribed in pre-existing custom and cosmology .... Yet it may well typify much Islamisation in the region [across the Indian Ocean] in allowing for Islamic and non-Islamic traits to inter-mingle steadily'. ${ }^{37}$

Lambek maintains that the local performances of the global Islamic texts provided the basis for a common religious identity shared by the worldwide 'umma (Ar., Muslim community), but the performances themselves responded to local needs and were embedded in local kinship and community:

People ... could not imagine an Islam that was not in part about fulfilling one's obligations and responsibilities to others, not according to an abstract ethics or code of law (though they were aware that this existed), but through the immediacy of habitual practice and according to the ways people expected to give and receive from one another on a daily and long-term basis. ${ }^{38}$

While this model fits well into the situation of the regions examined by this article, it is also true that not all Muslim communities along the Indian Ocean rim remained tolerant towards their pre- or non-Islamic practices. In other word, not all of them accepted rather than converted to Islam. This is particularly clear from the examples of the Southeast Asian regions other than the Minangkabau, and the Swahili coasts of Kenya and Tanzania just north of Mozambique, where matriliny was gradually replaced by patriliny or bilateral kinship. ${ }^{39}$ A closer look at these cases reveal that political power, in particular in Muslim states such as the sultanates of Java or Oman and Zanzibar, was probably essential for this kind of shift. Similar types of Muslim states were absent in Minangkabau, Kerala, and northern Mozambique, although some short-lived forms emerged here and there occasionally, and in Mozambique many coastal Muslims saw themselves as subjects of the Sultanate of Zanzibar until its fall in 1964, despite living under Portuguese rule.

\section{Islamic reformers, colonialism and matriliny}

The regions considered here were among the first to trade and later, to be colonised by the Europeans. The history of that interaction allows us to analyse three different colonial attitudes towards the coexistence of matriliny and Islam that Europeans encountered: the British, Dutch and the Portuguese. What were the consequences of these attitudes for the survival or transformations of the matriliny-Islam symbiosis?

36 Ibid.

37 David Parkin, 'Inside and outside the mosque: A master trope', in Parkin and Headley, Islamic prayer across the Indian Ocean: Inside and outside the mosque, p. 3.

38 Lambek, 'Localising Islamic performances', p. 74.

39 Kelly M. Askew, 'Female circles and male lines: Gender dynamics along the Swahili coast', Africa Today 46, $3 / 4$ (1999): 67-102; David Parkin, 'Swahili Mijikenda: Facing both ways in Kenya', Africa: Journal of the International African Institute 59, 2 (1989): 161-75. 
In the case of Mozambique, the Portuguese did not seem to have much knowledge or capacity to deal with Muslims, except for initial confrontations in the sixteenth and seventeenth centuries, when they conquered some Swahili enclaves along the coast but left others, such as Angoche, to remain independent of their incursions. $^{40}$

At the beginning of the modern colonial period, in the early twentieth century when the military conquests of the 'effective occupation' were almost concluded, the most important measures pertaining to Islam and matriliny had an administrative character aimed at organising colonies territorially and establishing a new bureaucratic system. The Administrative Reform legislations of 1907 and 1933 incorporated into the administrative machinery chiefs (wamwenye in the case of northern Mozambique) who were expected to rule according to local 'traditions and customs' while promoting metropolitan economic interests of collecting taxes and imposing forced labour. Significantly, women were not barred from exercising chieftaincy if that was the 'custom' of local people. ${ }^{41}$ The contents of African 'traditions and customs' were not addressed as Portugal did not have the same approach as other European colonies, neither did it boast of politicians or intellectual elites engaged in learning and translating Islamic religious sources written in Arabic comparable to that of other European regimes of the time. Although the chiefdoms and other territorial units were reorganised anew, which in effect disrupted the pre-existing structures and ideologies of Africans, Portugal insisted on selecting and endorsing chiefs whose legitimacy and authority were based on local 'customs and traditions'. ${ }^{42}$ This attitude to a certain extent safeguarded matriliny, because the chiefs and their retinues became responsible for the application of 'traditions and customs', with dispute arbitrations between the clan or family members with regard to property and inheritance left firmly in their hands.

Among the Islamic reformers who emerged in the mid-twentieth century under such names as sukuti (Ar., silent; those who opposed Sufism), 'Deobandis' (under the influence of the Indian Deobandi school) and the Wahhabis (those who studied in Saudi Arabia), almost none addressed matriliny. However, some men with a similar outlook but living in rural northern Mozambique and contesting for the positions of chiefs did try to eliminate matriliny or female leadership there. ${ }^{43}$ They were, however, unsuccessful due to African resistance and the Portuguese preoccupation with maintaining 'legitimate' chiefs in order to make the peasants produce what the metropolitan state needed. During the Estado Novo (1926-74), the Salazar regime allied

40 Bonate, 'Traditions and transitions'; Liazzat J.K. Bonate, 'Governance of Islam in colonial Mozambique', in Colonial and post-colonial governance of Islam, ed. Veit Bader, Annelies Moors and Marcel Maussen (Amsterdam: Amsterdam University Press, 2011), pp. 29-48.

41 Bonate, 'Matriliny, Islam and gender': $164 \mathrm{n} 8$.

42 Malyn Newitt, Portugal in Africa: The last hundred years (London: C. Hurst \& Co., 1981), pp. 100106; Harry G. West and Scott Kloeck-Jenson, 'Betwixt and between: “Traditional authority" and democratic decentralization in post-war Mozambique', African Affairs 98 (1999): 471; Bonate, 'Traditions and transitions'.

43 J.A.G. de M. Branquinho, 'Relatório da prospecção ao Distrito de Moçambique (Um estudo de estruturas hierárquicas tradicionais e religiosas, e da sua situação político-social), Nampula, 22 Apr. 1969’. SCCI, Secreto. Arquivo Histórico de Moçambique, Maputo, Secção Especial No. 20, Cotas S.E., 2 III P 6, Portugal, Lourenço Marques, 30 Dec. 1969, 32; Bonate, 'Matriliny, Islam and gender': 167. 
with the Catholic Church tried to impose Christianisation, but they realised the futility of this undertaking by 1954, when international pressure to decolonise Africa intensified. In the last decade of the colonial period, between 1964 and 1974, the regime undertook for the first time a systematic study of its Muslim colonial subjects to counteract the influence of the independence movements, but decolonisation dawned soon after so the policies elaborated from the newly-obtained knowledge were never implemented. ${ }^{44}$

The British, on the other hand, promoted Indirect Rule through 'native' administration and sought to systematise knowledge about their colonial subjects and introduce policies stemming from that process. Thus, in Malabar and Negeri Sembilan, British rule adopted a more legalistic approach to matriliny and Islam, whereby Islamic law ('the Muhammadan law') and 'customary law' were established and codified as clearly separate juridical and cultural domains. Thus, the rules of matrilineal kinship and inheritance, in the form of adat among the Minangkabau in Negeri Sembilan and the marumakkatayam in Kerala became 'customary laws' incorporating matriliny as opposed to Muhammadan Law, which codified what British perceived to be Shari'a and in which matriliny had no place. As a result, the British did not abolish the traditional system of clan offices and courts, but introduced previously absent Islamic courts and qadi offices leading to conflicts around the interpretation of local customs and the provisions of Shari'a. ${ }^{45}$ Peletz points out that adat in Negeri Sembilan, became 'subject to processes of rationalization and secularization' ${ }^{46}$ The notion of adat, as 'customary law' came to incorporate adat perpatih, which was based on local 'traditions and custom' among the Minangkabau and dealt with kinship, traditional titles, and women's prerogatives in proprietorship and inheritance. Adat temenggong prevailed among other Malays and had a more Islamic character. In general, as M.B. Hooker argues, adat in Negeri Sembilan became 'mainly concerned with detailed land rules'. ${ }^{47}$ It supplemented regulations on land tenure introduced by the British in Malaya, such as the Customary Tenure Enactments of 1909 and 1926, the Malay Reservation Enactment of 1913, and a new category of property known as Malay Reserve Land, access to which was barred to non-Malays.

But it was not only the British who stripped adat of its cultural meaning and made it more functional in terms of administering the territories and justice. ${ }^{48}$ In West Sumatra, the Dutch intervened in the early 1800s in the Padri wars, a religious conflict between Muslim groups initiated by clerics returning from the hajj in Mecca, where they witnessed the Wahhabi conquest, and declared jihad against Minangkabau adat back home. ${ }^{49}$ In particular, Syeh Achmad Chatib refused to accept matriliny

44 Bonate, 'Governance of Islam'.

45 M.B. Hooker, 'The early adat constitution of Negri Sembilan (1773-1824)', Journal of the Malaysian Branch of the Royal Asiatic Society 44, 1 (1971): 107; Peletz, A share of the harvest, pp. 99, 104-27.

46 Michael Gates Peletz, 'Comparative perspectives on kinship and cultural identity in Negeri Sembilan', Sojourn: Journal of Social Issues in Southeast Asia 9, 1 (1994): 40.

47 Hooker, 'The early adat constitution': 107; Peletz, 'Comparative perspectives on kinship', pp. 31, 33.

48 Peletz, 'Comparative perspectives on kinship': 7; Peletz, A share of the harvest, pp. 142-4.

49 Hadler, Muslims and matriarchs, pp. 23-33; Blackwood, Webs of power, p. 30; Kato, Matriliny and migration, pp. 94-101; Joel S. Kahn, Constituting the Minangkabau: Peasants, culture and modernity in colonial Indonesia (Oxford: Berg, 1993), p. 79; Gregory M. Simon, 'The soul freed of cares? Islamic prayer, subjectivity, and the contradictions of moral selfhood in Minangkabau, Indonesia', American 
among the Minangkabau. ${ }^{50}$ The Dutch intervened in favour of the adat proponents as opposed to the pilgrims. Thus, in addition to responding to conflicts related to Islam, the Minangkabau continually reconstituted adat in their interactions with the Dutch colonisers, who began codifying it after the 1830s. In particular, the Leiden School's legal historicism influenced by British approaches was instrumental in codifying adat. ${ }^{51}$ Malay intellectuals contributed to that process by responding to Dutch requests to write about adat, which they did in ways that made it seem more in line with Dutch legal thought. ${ }^{52}$ As Evelyn Blackwood argues, the resulting Minangkabau adat texts emerged in dialogue with the Dutch, Islam, and local oral tradition. ${ }^{53}$ In both Negeri Sembilan and West Sumatra the scope of adat was reconstituted and reduced, however, and the flexible and fluid oral tradition was codified by the colonial administrators and thus, 'frozen' in writing. ${ }^{54}$ Adat, which hitherto incorporated oral tradition on origins, customs, beliefs, and 'the proverbs that serve as guiding principles and rules for ceremonies, behaviours, and kinship relations', became confined to a concern with its implications for inheritance and control of harta pusaka (ancestral land)..$^{55}$

Similar conclusions could be drawn from the case of Malabar, where the British principles of Indirect Rule and Native Administration meant that local social and political hierarchies and land ownership remained largely in place, which enabled the Hindu higher castes to maintain the status quo with regards to their ownership of land. As in Malaya, the British set to codify local 'customary laws' in the nineteenth century by introducing the Malabar Marriage Act in 1896 and the Malabar Will Act in 1898, which enforced prevailing matrilineal customs, in particular the tharavadu (matrilineal corporate kinship property/land) as its central principle. ${ }^{56}$ And as in Southeast Asia, the legal reforms and the crystallisation of 'customary law' arose with the participation of local elites.

An important caveat to British and Dutch codifications of matrilineal rules was the colonial preoccupation with a father's self-acquired property, which often caused conflicts between his children and his matriclan. Dutch colonial courts in Indonesia consistently validated those adat rules that required the consent of the matrilineal

Ethnologist 36, 2 (2009): 282; Tsuyoshi Kato, 'Change and continuity in the Minangkabau matrilineal system', Indonesia 25 (1978): 2.

50 Franz von Benda-Beckmann and Keebet von Benda-Beckmann, 'Islamic law in a plural context: The struggle over inheritance law in colonial West Sumatra', JESHO 55 (2012): 782-3.

51 Saskia Wieringa, 'Matrilinearity and women's interests: The Minangkabau of Western Sumatra', in Subversive women: Women's movements in Africa, Asia, Latin America and the Caribbean, ed. Saskia Wieringa, 2nd ed. (London: Zed, 1997), pp. 242, 248;

52 Evelyn Blackwood, 'Representing women: The politics of Minangkabau adat writing', Journal of Asian Studies 60, 1 (2001): 126-7; Kahn, Constituting Minangkabau, pp. 127-8.

53 Blackwood, 'Representing women': 128.

54 Wieringa, 'Matrilinearity and women's interests', p. 242.

55 Kato, Matriliny and migration, pp. 33-4, 38; Blackwood, 'Representing women': pp. 126-7; Wieringa, 'Matrilinearity and women's interests'.

56 G. Arunima, There comes papa: Colonialism and the transformation of matriliny in Kerala, Malabar, c.1850-1940 (New Delhi: Orient Longman, 2003), pp. 15-25; Kunjulekshmi Saradamoni, Matriliny transformed: Family, law and ideology in twentieth century Travancore (New Delhi: Sage, 1999), pp. 86-110; Robin Jeffrey, 'Matriliny, women, development - and a typographic error', Pacific Affairs 63, 3 (1990): 375. 
heirs for donations of self-acquired property to children. ${ }^{57}$ In 1930 , a father was allowed to donate or will his self-acquired property without his matrilineal relatives' consent, but the intestate inheritance of self-acquired property remained subject to matrilineal principles. ${ }^{58}$ In Negeri Sembilan, today only harta pusaka is under adat perpatih, while self-acquired property is considered private property more often owned by men than women. ${ }^{59}$

The Malabar Marriage Act allowed members of any matrilineal caste to 'register' marriage, in which case laws governing bigamy, adultery, divorce and guardianship of children could be enforced, and a self-acquired property could become a bequest. ${ }^{60}$ The Malabar Will Act also allowed any matrilineal people to will any property which they could have given away while they were alive, especially self-acquired property; but in the absence of a will, matrilineal rules applied. In general, matrilineal principles governing the joint-family tharavadu property remained in place.

At the beginning of the twentieth century, the British delineated Malabar rules for specific ethnic or caste groups which included the 1912 Travancore Marumakkatayam Act, the 1918 Mappila Succession Act, the Nayar Act of 1925, and the Mappila Marumakkathayam Act of 1939. These laws also left the tharavadu basically unaltered, but non-registered traditional marriages were legalised allowing the wife and children the right to half of a husband's self-acquired property. ${ }^{61}$ Although G. Arunima claims that the senior male, karanavan, was transformed by the British into the pater familias of Roman law and undermined the position of senior women, the kandoti and female-headed households, in practice this seems to have remained largely unchallenged. ${ }^{62}$ Due to prevailing matriliny among them and in accordance with the British principle of 'customary' laws, the Malabar Muslims, in particular the Mappila, were barred from the application of the Anglo-Muhammaddan or Islamic laws being applied in northern India with regards to their land and inheritance rights, unless they renounced matriliny in favour of Islamic law. Otherwise, the customary laws encapsulating matriliny (the marumakkatayam) as codified by the British in Mappila Succession Act of 1918 and Mappila Marumakkathayam Act of 1939 were consistently enforced. ${ }^{63}$ As with other matrilineal peoples, the laws enabled the self-acquired property of a Mappila man who died intestate to bypass Muslim law and allowed equal sharing of the matrilineal property among male and female members of the family. However, in the Lakshadweep Islands, according to Dube, the difference between the tharavadu property (the so-called 'Friday property') and self-acquired property ('Monday property'), was already entrenched historically. ${ }^{64}$ The Friday property was expected to be inherited matrilineally; while the Monday property, which was usually acquired by purchase,

57 Von Benda-Beckmann and Von Benda-Beckmann, 'Islamic law in a plural context': 783.

58 Ibid.: 788 .

59 Karim, Women and culture, p. 63.

60 Jeffrey, 'Matriliny, women, development': 374-5; Manaf Kottakkunnummal, 'Contestations in religion, gender, and family among matrilineal Mappila Muslims in colonial Malabar, Kerala, c. 19101928', SAGE Open 4, 1-12 (2014), DOI: 10.1177/2158244014525416.

61 Jeffrey, 'Matriliny, women, development': 375-6; Kottakkunnummal, 'Contestations in religion'.

62 Arunima, There comes papa, pp. 20-25, 95.

63 Sebastian, 'Matrilineal practices': 73-9; Kottakkunnummal, 'Contestations in religion'.

64 Dube, Matriliny and Islam, p. 36. 
either was inherited through the Shari'a provisions or when a man was the sole heir, governed by the Shari'a rules.

Similar to northern Mozambique and the Minangkabau, in Kerala Muslim reformers appeared in the nineteenth and early twentieth centuries. The Mambran and Kondotti thannals had been politically active since the nineteenth century, leading or significantly influencing the Mappila revolts and jihads against the British reforms and the Hindu communities, but they did not challenge matriliny or Sufism. ${ }^{65}$ In the 1920s, several thangal critical of local practices and conceptions of Islam surfaced under the influence of the Egyptian reformers Muhammad Abduh (1849-1905) and Rashid Ridda (1865-1935). The most important was Vakkom Maulavi (18731932). He and his followers were staunch opponents of what they perceived to be shirk (Ar., idolatry) and bid'a (Ar., abominable religious innovations), including Sufism and matriliny. ${ }^{66}$ The Nadvat-ul-Mujahideen movement that emerged in the 1930s and formally organised in 1952, continued in the same anti-Sufi and antimatriliny vein as the earlier reformers. ${ }^{67}$ But they were unable to alter matriliny to a great extent, at least in the form codified by British rule.

\section{Matriliny compared: Post-colonial context}

My own research and that of Isabel Casimiro, Signe Arnfred, Daria Trintini and Carla Braga indicate that matriliny is still alive among Muslim communities of northern Mozambique despite post-colonial attempts to modernise, secularise and even eliminate related ideas and practices. ${ }^{68}$ The same could be said about the Mappila and Koyas of Kerala and Lakshadweep, and the Minangkabau. This does not mean that matriliny has not been altered or has not been undergoing continual transformation, but it is more and more centred on so-called ancestral land, rather than other types of property. As in the colonial period, the 'escape' so to speak, from the control of the matrilineal kin group leading to individualisation of rights comes through the rules for so-called self-acquired property. This kind of property is owned mostly by men; it can be disposed of individually and it can be inherited by direct descendants rather than the matriclan at large, either in accordance with the statutory laws or the Islamic Shari'a.

Thus, in all regions examined in this article, matrilineal descent groups are constituted around ancestral land, owned by corporate descent groups, but inherited

65 Dale, Islamic society.

66 Miller, Mappila Muslims of Kerala, pp. 270-73; Sebastian, 'Matrilineal practices': 80-81.

67 Miller, Mappila Muslims of Kerala, pp. 275-82; Sebastian, 'Matrilineal practices': 80-81.

68 Liazzat J.K. Bonate, 'Women's land rights in Mozambique: Cultural, legal and social contexts', in Women and land in Africa: Culture, religion, and realizing women's rights, ed. L. Muthoni Wanyeki (London: Zed, 2003), pp. 96-133; Isabel Casimiro, 'Cruzando lugares, percorrendo tempos: Mudanças recentes nas relações de género em Angoche' (PhD diss., University of Coimbra, 2008); Signe Arnfred, Sexuality and gender politics in Mozambique: Rethinking gender in Africa (Uppsala: Nordic Africa Institute; Oxford: James Currey, 2011); Daria Trentini, 'On the threshold of a healer's mosque: Spiritual healing, hazard and power in northern Mozambique' (PhD diss., SOAS, University of London, 2012); Carla Braga, “"They're squeezing us!” Matrilineal kinship, power and agricultural policies: Case study of Issa Malnaga, Niassa Province', in Strategic women, gainful men: Gender, land and natural resources in different rural contexts in Mozambique, ed. Rachel Waterhouse and Carin Vijfhuizen (Maputo: Núcleo de Estudos de Terra, Eduardo Mondlane University and ActionAid-Mozambique, 2001), pp. 199-225. 
through female lines, with overlapping rights of disposal vested in matrilineal kin groups. Individuals within these groups only have usufruct rights. Among the Minangkabau, both in West Sumatra and Negeri Sembilan, such land is classified as harta pusaka belonging to a village (nagari) that consists of several ideally exogamous matriclans, suku, divided into several matrilineages $(\mathrm{kaum})$ with ceremonially instituted male head called the penghulu or mamak. ${ }^{69}$ The suku are defined by the claim of a common ancestress (bundo kanduang) and sa pariuk (one womb), and they usually own a longhouse, belonging to the women, and possess the land. The land (its use, distribution, and income) is controlled by the senior woman along with the penghulu (or mamak within the smaller units), usually her brother or maternal uncle. ${ }^{70}$ The ideas and practices of matriliny among the Minangkabau currently are related to the old social and cultural system known as adat perpatih, which according to Peletz, 'was grounded in pre-Islamic (that is, Hindu-Buddhist and pre-Indic) beliefs and practices in a rich corpus of oral tradition', but which was codified under pressure from Islamic reformers and Dutch and British colonial rulers in the nineteenth century. ${ }^{71}$

Land is central to the Muslims of Kerala too, especially for the land-owning Koyas, who having emerged from the upper caste Hindu Brahmins and Nayars, held views similar to them in this regard. Among the Nayars, land which 'passed from generation to generation through women, was the foundation of matriliny'. ${ }^{72}$ Similar to the case of the Minangkabau, for Nayars as well as land-owning Koyas of the Lakshadweep Islands and the Mappila of Kerala, the central kinship group has been a maternal lineage or clan termed tharavadu, consisting of a group of men and women tracing descent from a common ancestress (thus they are the 'children of one womb'), and living under the control and management of the eldest male, called karanavar, the oldest woman's, or karnoti's uncle, brother or son. ${ }^{73}$ Karnoti, the eldest woman, enjoys a special status; she is consulted by the karanavar in all important matters. ${ }^{74}$ The smallest unit is called thavari, which could be regarded as a segment descended from each woman of a tharavadu. It owns the joint family house also known as a tharavadu. Similar to the case of the Minangkabau's adat perpatih, largely pre-Islamic Hindu-based matrilineal traditions were codified under pressure from the British colonial regime in legal corpuses known as marumakkathayam, matrilineal customary laws, and in particular for the Mappila, as the Mappila Marumakkathayam.

In contrast to the Minangkabau and Kerala, the northern Mozambican matrilineal peoples did not possess a joint family house, but rather individual family units lived in separate residences. Today as before, the rural population lives in dispersed

69 Peletz, A share of the harvest, p. 18; Blackwood, Webs of power, pp. 70-74; Evelyn Blackwood, 'Women, land and labour: Negotiating clientage and kinship in a Minangkabau peasant community', Ethnology 34, 4 (1997): 138, 279; Kahn, Constituting Minangkabau, p. 41.

70 Blackwood, 'Women, land and labour': 281.

71 Peletz, A share of the harvest, p. 18. See also, Karim, Women and culture, pp. 63-4.

72 Saradamoni, Matriliny transformed, p. 34.

73 Saradamoni, Matriliny transformed, pp. 9, 62-3; Kutty, Marriage and kinship, pp. 87-116, 127; Dube, Matriliny and Islam, pp. 27-8, 37; Sebastian, 'Matrilineal practices': 71-2; Dale, Islamic society, pp. 24.

74 Dube, Matriliny and Islam, p. 40; Sebastian, 'Matrilineal practices': 73. 
communities with individual houses scattered around some distance from each other, unless it is a village organised by the state. Otherwise, the perceptions pertaining to kinship and land have a lot in common with the Minangkabau and the matrilineal peoples of Kerala. Here, the ancestral land belongs to a kinship group called maloko (pl., sing. n'loko) descending from a common female ancestor symbolically identified as errukulo ('a womb') or nipele ('a breast'). ${ }^{75}$ Each n'loko consists of several smaller kinship groups - nihimo (sing., pl. mahimo). The male head of each n'loko is mwenye n'loko; and of each nihimo is humu or mwenye nihimo. A senior woman, the elder uterine sister of the mwenye, is called piya-mwenye (literally, the female mwenye) or nunu. Each clan has its own senior man, a maternal uncle or brother of the senior woman called tata or halu. ${ }^{76}$ As with the Minangkabau and Kerala, senior women and men overlook and control the distribution and use of land, regulate relationships between members of the original kin groups and the newcomers, and settle disputes and oversee internal family matters as well.

In all the regions under consideration, it is incumbent upon the eldest man, be it a mamak, karanavar, or atata to take care of his sister's children, as well as play the role of guardian (wali) for his nieces in Islamic weddings (adat, nikah or chuo), and arrange and oversee their marriage partners as well as their divorce and remarriage, and negotiate their dower (mahr). ${ }^{77}$ Thus, children belong to the matriclan, and are under the care of the eldest woman and her brother/maternal uncle. The father has no responsibility towards them, although nowadays he often pays for their schooling and other expenses. Upon divorce, which is quite common in all four regions, children are left with the mother or her matriclan; upon the death of the husband, his matriclan has no responsibility towards the children (although the attitude varies nowadays according to individual families).

The land rights of a lineage or clan among the Minangkabau and coastal northern Mozambique are derived from an idea of a first-comer status, while among the land-owning Koyas through the Hindu principle of birthright, janmon, which, broadly-speaking, also stands for the first-comer status. Thus, in all regions under consideration, most of the land is owned by the traditional elites, and access to land comes through the elites. What Blackwood underscores for the Minangkabau is true for the other two regions as well: those who are not considered descendants of the original settlers are clients of these clans with regards to the land, and 'although bracketed within kinship ideology, their relationship is one of patron and client'. ${ }^{78}$ In the case of the Minangkabau, suku are frequently differentiated internally according to whether they were direct descendants of the original settlers of the nagari, or of

75 Eduardo do Couto Lupi, Angoche: Breve memória sobre uma das Capitanias-Môres do Distrito de Moçambique (Lisboa: Typografia do Annuario Commercial, 1907), pp. 162-7; Joseph Frederic Mbwiliza, A history of commodity production in Makuani 1600-1900: Mercantilist accumulation to imperialist domination (Dar Es Salaam: Dar Es Salaam University Press, 1991), pp. 69-71; A.J. de Mello Machado, Entre os macuas de Angoche: Historiando Moçambique (Lisboa: Prelo, 1970), pp. 391-2; Nancy Jane Hafkin, 'Trade, society, and politics in northern Mozambique, c. 1753-1913' (Ph.D diss., Boston University, 1973), pp. 49-50, 204-5; Bonate, 'Women's land rights in Mozambique'.

76 Bonate, 'Traditions and transitions'; Casimiro, 'Cruzando lugares, percorrendo tempos'.

77 Kato, Matriliny and migration, pp. 52, 212; Dube Matriliny and Islam, pp. 54-5, 68; Bonate, 'Women's land rights'.

78 Blackwood, 'Women, land and labor': 282. See also, Kahn, Constituting Minangkabau, p. 155. 
latecomers. ${ }^{79}$ In wider geographic terms, people from the Minangkabau heartland mountains are called darek, the first-comers, 'who feel superior to merantau, the inhabitants of the shoreline, rantau'. ${ }^{80}$ The arang asa (descendants of original settlers in West Sumatra) and the waris ('heirs to the soil' in Negeri Sembilan) are considered kemanakan beneath the chin, those whose ancestors were the original settlers, while kemanakan beneath the navel are considered to be their relations by favour, and the third group kemanakan beneath the knees allegedly descended from debt bondsmen, prisoners of war, or purchased slaves. ${ }^{81}$

In coastal northern Mozambique, exemplified here by Angoche, the alleged firstcomers are called the Anhapakho. ${ }^{82}$ This group is constituted of four major clans (nhandare, nhamilala, nhatide and m'bilinzi), descendants of four sons of the mythical woman founder. The Anhapakho are considered to be the putative first-comers who 'own' the land, thus, they are the wamwenye (the landowning elites). In this quality, they oversaw its distribution to the later arrivals to whose allegiance they had special claims through marriage and kinship relations. The latecomers were expected to receive a portion of land from the first-comers in return for tribute and loyalty. Nowadays this relationship is expressed by payment of cash, crops or other goods.

The situation of the Mappila Muslim clans of Malabar, referred to as 'children of the same womb', differs from Minangkabau and northern Mozambique in that Hindu social organisation and perceptions prevailed before the conversion to Islam, and the caste system was transported into the nascent Muslim community. While the upper caste Brahmins and Nayars maintained their janmon land rights after conversion but were a minority, the converts from the lower castes, who were the majority, remained landless. This, according to Stephen F. Dale, led to various revolts and jihads by the Mappila that punctuated Malabar history between 1489 and 1922, and even after Independence and the partition of India. ${ }^{83}$

In all cases, the duolocal residence pattern of the earlier periods, when a married man did not reside with his wife but visited her daily while residing with his own matriclan, has been transforming into a more uxorilocal pattern since the midtwentieth century. ${ }^{84}$ Of course, this varies according to the situation of the individual families, especially when they migrate to the cities or other regions. Thus, features of the idealised matrilineal kinship system are not always strictly followed nowadays. Modern Western education and employment, transnational experiences, such as in Gulf countries where stricter Islam is followed, and economic transformations in agriculture and in societies at large, have been engendering many changes. Inheritance

79 Karim, Women and culture, pp. 70, 76.

80 Thomas Reuter, 'Precedence in Sumatra: An analysis of the construction of status in affinal relations and origin groups', Bijdragen tot de Taal-, Land-, en Volkenkunde 148, 3/4 (1992): 514-15.

81 Kato, Matriliny and migration, p. 63; Peletz, A share of the harvest, p. 25.

82 Lupi, Angoche, pp. 70, 114-15, 135, 173, and passim; João de Azevedo Coutinho, As duas conquistas de Angoche (Lisboa: Divisão de Publicações e Biblioteca, Agência Geral das Colónias, 1935), p. 91; Liazzat J.K. Bonate, 'The ascendance of Angoche: Politics of kinship and territory in the nineteenth century northern Mozambique', Lusotopie 1 (2003b): 121-2; Bonate, 'Traditions and transitions'.

83 Ilias, Mappila Muslims of Kerala, p. 117; Dale, Islamic society; P. Rashakrishnan, 'Peasant struggle and land reform in Malabar', Economic and Political Weekly 15, 50, 13 Dec. 1980, pp. 2095-2102.

84 Kato, Matriliny and migration, p. 214; Kahn, Constituting Minangkabau, p. 41; Dube, Matriliny and Islam, p. 43; Sebastian, 'Matrilineal practices': 74; Bonate, 'Traditions and transitions'. 
and ownership of other property that is not the ancestral land could have become more patrilineal, the residence pattern might vary from uxorilocal to patrilocal or even independent, and the power of the nominal heads of clans, be they women or men, could be reduced to overseeing the ancestral land or sorting out family disputes. But so far, the ancestral land itself remains the common point that sustains matriliny in all the regions examined in this article.

\section{Conclusion}

Despite the expansion of Islam for several centuries, the regions under consideration have conserved a matriliny that preceded the advent of Islam. Islam came through peaceful trade and through the acceptance of local populations rather than through force or an abrupt conversion. This left many pre-existing ideas and practices, such as matriliny, in place. The Islamists of the nineteenth and twentieth centuries tried to confront and even ban matriliny, but the interference of European colonialism weakened their power and resolve in pursuing this goal. The Dutch and the British colonial regimes tried to systematise local customs in order to better control subject populations. With the help of local elites, they codified matriliny in the form of adat perpatih among the Minangkabau and marumakkathayam 'customary law' in Malabar. Although they left room for the application of the Islamic Shari'a and patrilineal inheritance through the endorsement of self-acquired property as being free from the control of the matrilineal kin group, the fact that matriliny was codified at all, guaranteed its survival. In contrast to the British and the Dutch, the Portuguese colonial state did not attempt to codify any 'customary' or Islamic laws, but by integrating matrilineal chiefs into the official administrative system, it had also perpetuated matriliny.

Despite this long-term survival, matriliny has been under strain from various sides especially during the post-colonial period due to economic and political changes related to modernisation projects of nationalist states, the neo-liberal turn of the late 1980s, and the influence of transnational Islamist tendencies. Although this might vary among different regions and from one individual family to another, it appears that the feature common to all the regions which still hold matriliny alive is the existence and legal recognition of the ancestral land of kinship groups or families. This land is not only a piece of soil but embodies the history and myths of the matrilineal families and roots them in specific territories as the fundamental blocks in scaffolding their identities. 